Abdel Aziz Fouda ${ }^{1 *}$, Asmaa A. Idress ${ }^{2}$, Mohamed F. Atia ${ }^{3}$, Mohamed E. Yassen ${ }^{4}$

Scientific paper

ISSN 0351-9465, E-ISSN 2466-2585

UDC: 546.62:665.7.038.5:661.12

${ }^{1}$ Chemistry Department, Faculty of Science, Mansoura University, Mansoura- 35516, Egypt, ${ }^{2}$ Chemistry Department, Faculty of Science, Omar AL mukhtar University, Elbeida, Libya, ${ }^{3}$ Faculty of Technological Industry and Energy, Delta Technological University, Qewasnia, El-Menoufia, Egypt, ${ }^{4}$ Basic Sci. Depart., Higher Institute of Engineering and Technology, Tanta, Egypt

\title{
Candesartan: a pharmaceutical product as effective corrosion inhibitor for Aluminum in Acidic Solution
}

\begin{abstract}
The corrosion performance of aluminum in $1 \mathrm{M}$ hydrochloric acid solution in the existence and absence of Candesartan drug was examined utilizing, potentiodynamic polarization (PDP) and AC impedance (EIS) tests. It was found that the inhibition efficacy (\%IE) of Candesartan drug was influenced by its doses and temperature and reached to $92.9 \%$ at $40 \times 10^{-6} \mathrm{M}, 30^{\circ} \mathrm{C}$. The adsorption isotherm agreed with Langmuir model. From Tafel data the investigated Candesartan drug acts as mixed kind inhibitor. The influence of temperature on the rate of dissolution and the thermodynamic parameters in the existence and absence of Candesartan drug were also, studied and explained. All tests gave similar results.
\end{abstract}

Keywords: Corrosion inhibition, aluminum, $\mathrm{HCl}$, Candesartan drug, adsorption, impedance, polarization.

\section{INTRODUCTION}

Aluminum and its alloys have been the subject of numerous studies due to their high technological value and wide range of industrial applications, especially in the aerospace and household industries. On the other hand, Al and its alloys are corrosive and reactive materials. Aluminum corrosion resistance is based on the formation of a lightweight, adherent passive oxide film in a variety of environments. This amphoteric surface film dissolves significantly when the metal is exposed to high doses of acids or bases [1]. The key technique for preventing electrochemical corrosion of $\mathrm{Al}$ is to effectively separate the metal from corrosive medium. Corrosion inhibitors may be used to do this. Inhibitors are one of the most well-known methods of corrosion safety. The effectiveness of organic compounds used as inhibitors is affected not only by the atmosphere in which they function, but also by the nature of the metal surface, the electrochemical potential at the interface. The inhibitors work by the adsorption on the metal surfaces. The number of adsorption active centers

${ }^{*}$ Corresponding author: Abdel Aziz Fouda

E-mail: asfouda@hotmail.com

Paper received: 03. 05. 2021.

Paper accepted: 15. 07. 2021.

Paper is available on the website: www.idk.org.rs/journal in a molecule, their charge density, molecular size, adsorption mode, formation of metallic complexes, are all factors to be consider [2,3]. Corrosion inhibitors with functional groups containing heteroatoms capable of donating lone pairs of electrons have been found to be especially useful [4-10]. Compounds with m-bonds, on the other hand, have good inhibitive properties because they allow electrons to interact with the metal surface. [11-15]. Both characteristics can, of course, be found in the same molecule, such as narcotics. The conventional approach to the selection of corrosion inhibitors has gradually changed in recent years, owing to the increasing concern and attention of the world towards environmental issues and environmental safety, as well as the dangerous effects of chemical use on ecological balance [1619]. Recently research efforts have been done on the utilize of antibacterial drugs as corrosion inhibitors for carbon steel and $\mathrm{Al}$ in acidic and alkaline media [20-26]. The use of many types of drugs as corrosion inhibitors of various metals was collected by Gokhan Gece [27] in a review. The inhibitive effect some antibacterial drugs, namely Ampicillin, Cloxacillin, Flucloxacillin and Amoxicillin towards the corrosion of Al was investigated [28]

Among these cephalosporins, cefadroxil, cefazolin and cefalexin are utilized as corrosion inhibitors of $\mathrm{Fe}$ in acidic media [29-32]. Candesartan drug, which is the subject of this study, is non-toxic, inexpensive, and environmen- 
tally friendly medications used to treat hypertension. It has reactive centers like $\mathrm{N}, \mathrm{O}$ atoms with lone pairs of electrons and aromatic rings with delocalized $\pi$ - electron systems, which can aid adhesion to metal surfaces. Furthermore, it has high molecular weight and is more likely to efficiently cover more surface area of the metal, avoiding corrosion. The drug Candesartan has the following chemical structure:
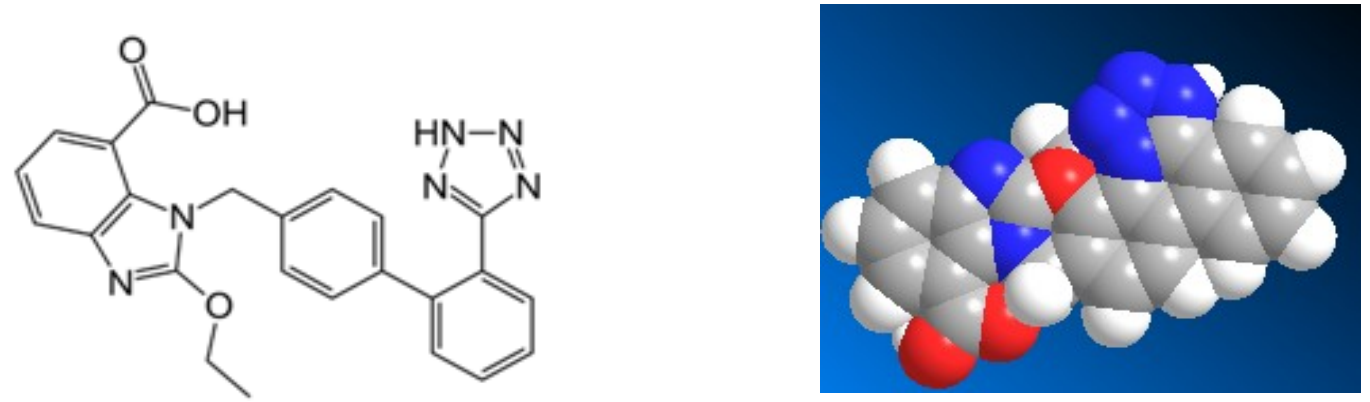

2-ethoxy-3-[[4-[2-(2H-tetrazol-5-yl) phenyl] phenyl] methyl] benzimidazole-4-carboxylic acid. Molecular Weight $=440.45$, Chemical Formula: $\mathrm{C}_{24} \mathrm{H}_{20} \mathrm{~N}_{6} \mathrm{O}_{3}$, Hemijska formula $-\mathrm{C}_{24} \mathrm{H}_{20} \mathrm{~N}_{6} \mathrm{O}_{3}$

\section{EXPERIMENTAL DETAILS}

In this analysis, Al metal with a purity of 99.99 percent was given from the "Al Company of Egypt, Nagh Ammady." "For anodic and cathodic Tafel polarization measurements, as well as AC impedance measurements, a cylindrical rod embedded in araldite with an exposed surface area of $1.0 \mathrm{~cm}^{2}$ was used. Prior to each experiment, the surface of Al specimens was mechanically polished with different grades of emery papers, degreased with the alkaline solution $\left(15 \mathrm{~g} \mathrm{Na}_{2} \mathrm{CO}_{3}+15 \mathrm{~g}\right.$ $\mathrm{Na}_{3} \mathrm{PO}_{4}$ per liter), and rinsed with distilled water. GAMRY PCl4/300 electrochemical work station. Potentiostat/Galvanostat was utilized to calculate anodic and cathodic polarization. In three compartment cells, a saturated calomel reference electrode (SCE) and a platinum foil auxiliary electrode were used. A JASCO UV-vis 530 spectrophotometer was used to take both spectral measurements. Chemicals and reagents of analytical grade were used. The drug was supplied from a variety of pharmaceutical companies. In a stock solution, 1000 ppm" [33] were made by dissolving the required weight of drug $(1 \mathrm{~g})$ in a small amount of one molar $\mathrm{HCl}$. Using a water thermostat set to $\pm 0.5{ }^{\circ} \mathrm{C}$, measurements were taken at $30-50{ }^{\circ} \mathrm{C}$.

\section{RESULTS AND DISCUSSION}

\subsection{Potentiodynamic polarization (PDP)) technique}

It is possible to obtain important data about the kinetics of the cathodic and anodic reactions using the PDP technology [34]. Figure 1 demonstrations typical anodic and cathodic PDP diagrams for Al in $1 \mathrm{M} \mathrm{HCl}$ in attendance and absence of varying Candesartan drug doses, the following parameters were obtained: electrochemical corrosion potential
$\left(E_{\text {corr }}\right)$, corrosion current density $\left(I_{\text {corr }}\right)$, polarization resistance $\left(R_{p}\right)$ and cathodic and anode Tafel constants $\left(\beta_{c}, \beta_{a}\right)$, respectively. From the values in Table 1 , in the presence of different doses of Candesartan drug, there is a decrease in the current density and the decrease increases with increasing dose, indicating the formation of a layer from the drug molecules on the Al surface. Moreover, the values of the cathode and anode Tafel slopes have no sharp difference in the existence of changed doses from Candesartan drug, Fig. 1. This can be explained by the fact that the dissolution procedure is caused by covering the active sites located on the surface of the Al. This also indicates that the dissolution mechanism that is not affected by the presence of Candesartan drug [33]. If the variation in corrosion potential $\left(E_{\text {corr }}\right)$ values is more than $\pm 85 \mathrm{mV}$ in the presence and absence of Candesartan drug, the inhibitor molecules are named anodic or cathodic type and this did not happen because, the potential of corrosion values displacement fewer than $\pm 85 \mathrm{mV}$ [35]. The difference in $E_{\text {corr }}$ values is small $(9 \mathrm{mV})$ and this assured that the Candesartan drug works as a mixed type of inhibitor. Finally, from Table (1) we can conclude that as the dose of Candesartan drug rises, the current density decreases, the \%l increases, the corrosion rate reduced, and the polarization resistance raises due to the increase thickness of the adsorbed layer, Table 1.

The following equation was used to measure the $\%$ I from the corrosion current density $\left(I_{\text {corr }}\right)$ :

$$
1 \%=\left[1-\left(I_{\text {corr, add }} / I_{\text {corr, free }}\right)\right] \times 100
$$

where $I_{\text {corr,free }}$ and $I_{\text {corr,add }}$ are the corrosion current in the absence and presence of Candesartan drug, correspondingly. 
Table 1. PDP data of $A l$ in $1 \mathrm{M} \mathrm{HCl}$ with and without altered doses of Candesartan drug at $30^{\circ} \mathrm{C}$

Tabela 1. PDP podaci o Al u $1 \mathrm{M} \mathrm{HCl}$ sa i bez izmenjenih doza leka Candesartan na $30^{\circ} \mathrm{C}$

\begin{tabular}{|c|c|c|c|c|c|c|c|}
\hline [Inh.], ppm & $-\mathrm{E}_{\text {corr }}, \mathrm{mV}$ & $\mathrm{I}_{\text {corr }} \mathrm{mA} \mathrm{cm}$ & $-\beta_{\mathrm{c}}, \mathrm{mV} \mathrm{dec}^{-1}$ & $\beta_{\mathrm{a}}, \mathrm{mV} \mathrm{dec}^{-1}$ & $\mathrm{R}_{\mathrm{p}}, \Omega \mathrm{cm}^{2}$ & $\theta$ & $\mathrm{I} \%$ \\
\hline Blank & 782 & 48.96 & 96 & 57 & 5.017 & ---- & ---- \\
\hline 10 & 790 & 10.61 & 83 & 45 & 11.920 & 0.657 & 74.1 \\
20 & 791 & 9.85 & 85 & 45 & 12.970 & 0.682 & 79.9 \\
30 & 788 & 7.18 & 80 & 43 & 13.300 & 0.703 & 85.3 \\
40 & 789 & 5.14 & 80 & 43 & 14.880 & 0.737 & 89.5 \\
\hline
\end{tabular}

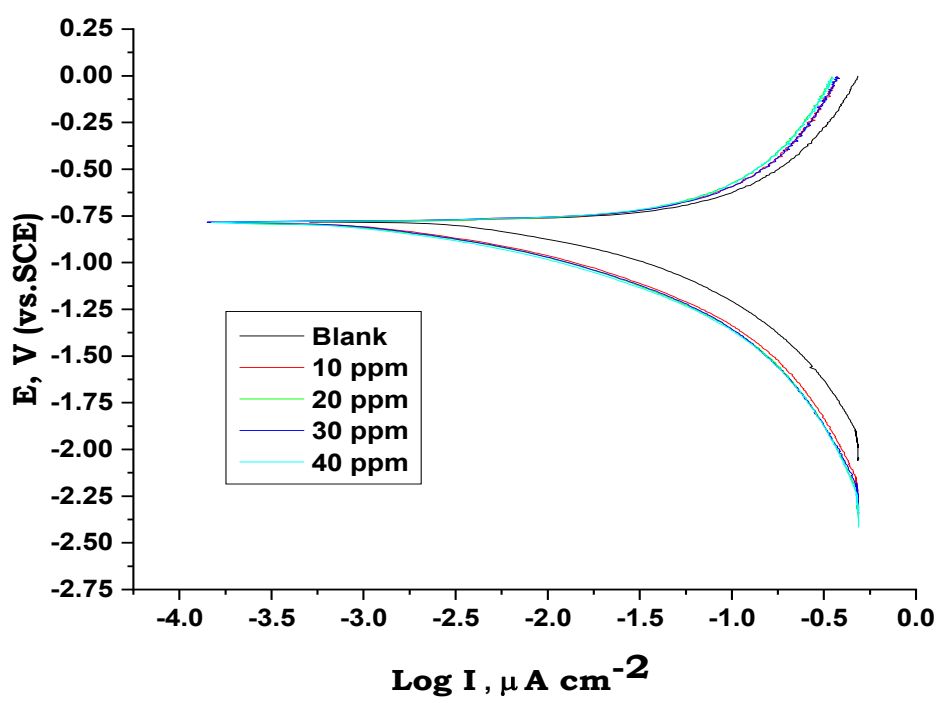

Figure 1. PDP curves for $\mathrm{Al}$ dissolution in $1 \mathrm{M} \mathrm{HCl}$ with and without altered Candesartan drug doses at $30^{\circ} \mathrm{C}$

Slika 1. PDP krive za rastvaranje $\mathrm{Al}$ u $1 \mathrm{M} \mathrm{HCl}$ sa i bez izmenjenih doza leka Candesartan na $30^{\circ} \mathrm{C}$

\subsection{Adsorption isotherms}

Candesartan adsorbed on the surface of the Al electrode is observed as a substitutional adsorption procedure between Candesartan in the aqueous phase $\left(\mathrm{Org}_{\mathrm{aq}}\right)$ and $\mathrm{H}_{2} \mathrm{O}$ molecules adsorbed on the Al surface [35].

$\operatorname{Org}_{(s o l)}+x\left(\mathrm{H}_{2} \mathrm{O}\right)_{a d s} \rightarrow \operatorname{Org}(a d s)+x \mathrm{H}_{2} \mathrm{O}_{(\text {sol) }}$ where $x$ is the size ratio, that is, the amount of $\mathrm{H}_{2} \mathrm{O}$ molecules exchanged by one organic molecule. Langmuir adsorption isotherm was by far the best match for the results. Plotting log $\mathrm{C} / \theta$ against $\log \mathrm{C}$ yielded a straight line with a unit slope value, Fig. 2 , suggesting that Candesartan drug adsorption on Al surface obeys Langmuir isotherm. These findings lead to the conclusion that there is no interaction among the adsorbed types.

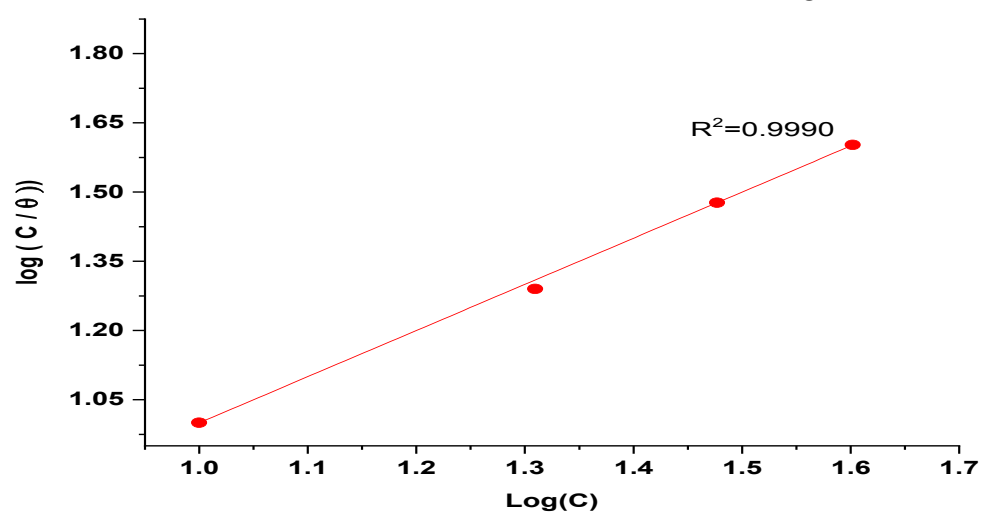

Figure 2. Langmuir adsorption isotherm achieved from $P D P$ for $A$ l dissolution in $1 \mathrm{M} \mathrm{HCl}$ with and without altered doses of Candesartan drug at $30^{\circ} \mathrm{C}$

Slika 2. Langmuirova adsorpciona izoterma postignuta iz PDP za rastvaranje $\mathrm{Al}$ u $1 \mathrm{M} \mathrm{HCl}$ sa i bez izmenjenih doza leka Candesartan na $30^{\circ} \mathrm{C}$ 


\subsection{Effect of temperature}

PDP tests were utilized to assess the impact of temperature on the rate of dissolution of "Al in $1 \mathrm{M}$ $\mathrm{HCl}$ containing $40 \mathrm{ppm}$ of Candesartan drug over a temperature range of 30 to $50{ }^{\circ} \mathrm{C}$. From PDP tests, the effect of improving temperature on the rate of corrosion ( $\left.I_{\text {corr }}\right)$ and $1 \%$ was studied. The outcome data exposed that, on improving temperature there is a rise in the $I_{\text {corr }}$ while $1 \%$ lowered i.e. the drug was adsorbed physically on Al surface. The activation energy $\left(E_{a}\right)$ of the dissolution procedure was measured utilizing Arrhenius equation" [36]:

$$
I_{\text {corr }}=A \exp ^{-E a^{*} / R T}
$$

where $I_{\text {corr }}$ signifies the rate of dissolution, and $T$ is kelvin temperature.

Figure 3 signifies Arrhenius drawn (log $I_{\text {corr }}$ vs. $1 / \mathrm{T}$ ) for unprotected and protected $1 \mathrm{M} \mathrm{HCl}$ inclosing $40 \mathrm{ppm}$ of the Candesartan drug. The $E^{*}$ data can be observed from the slope of the straight lines. As in Table 2 the rise of the $E_{a}^{*}$ in the existence of Candesartan drug is qualified to an appreciable lowered in the adsorption procedure of the Candesartan drug on the Al surface with improving the temperature and a conforming rise in the reaction rate due to the greater area of the metal that is exposed to the $\mathrm{HCl}$ [37].

$\Delta \mathrm{S}^{*}$ and $\Delta \mathrm{H}^{*}$ for $\mathrm{Al}$ dissolution in $1 \mathrm{M}$ hydrochloric acid in the presence of $40 \mathrm{ppm}$ of utilized Candesartan were achieved by applying the transition state equation:

$$
\begin{aligned}
& \log I_{c o r} / T=\log \left(R / N h+\Delta S^{*} / 2.303 R\right)+ \\
& +\left(-\Delta H^{*} / 2.303 R T\right)
\end{aligned}
$$

where " $(\mathrm{h})$ is the Planck's constant and $(\mathrm{N})$ gives the number of Avogadro. Fig. 4 shows straight lines resulting from a drawing log $\left(I_{\text {corr }} / T\right)$ with $1000 / T$, where this figure shows the transitional state of the Candesartan drug.

The analysis of the results was obtained in Table 2, from Table 2 there is an increase in the $\mathrm{E}_{\mathrm{a}}^{*}$ by improving the dose of Candesartan drug. This improve is due to the adsorption nature of Candesartan drug on the Al surface and corresponds to the physical adsorption of the molecules of Candesartan drug on Al surface. The results in Table 2 also showed that entropy values are negative in the existence of Candesartan drug". We conclude from this that the initial condition was less arranged than that found in the active molecules of Candesartan drug [38].

Table 2. Activation results for dissolution of $\mathrm{Al}$ in $1 \mathrm{M} \mathrm{HCl}$ at $40 \mathrm{ppm}$ Candesartan drug

Tabela 2. Rezultati aktivacije za rastvaranje Al u $1 \mathrm{M} \mathrm{HCl}$ na 40 ppm leka Candesartan

\begin{tabular}{|c|c|c|c|}
\hline $\begin{array}{c}-\mathrm{ÄS}^{*}, \\
\mathrm{~J} \mathrm{~mol}^{*}{ }^{-1}\end{array}$ & $\begin{array}{c}\mathrm{ÄH}^{\star}{ }^{*} \\
\mathrm{~kJ} \mathrm{~mol}^{-1}\end{array}$ & $\begin{array}{c}\mathrm{E}_{\mathrm{a}}{ }^{*}, \\
\mathrm{~kJ} \mathrm{~mol}^{-1}\end{array}$ & Inhibitor \\
\hline 199.5 & 12.11 & 7.95 & $\begin{array}{c}\text { Free } \\
\text { acid }\end{array}$ \\
\hline 194.7 & 25.04 & 17.73 & drug \\
\hline
\end{tabular}

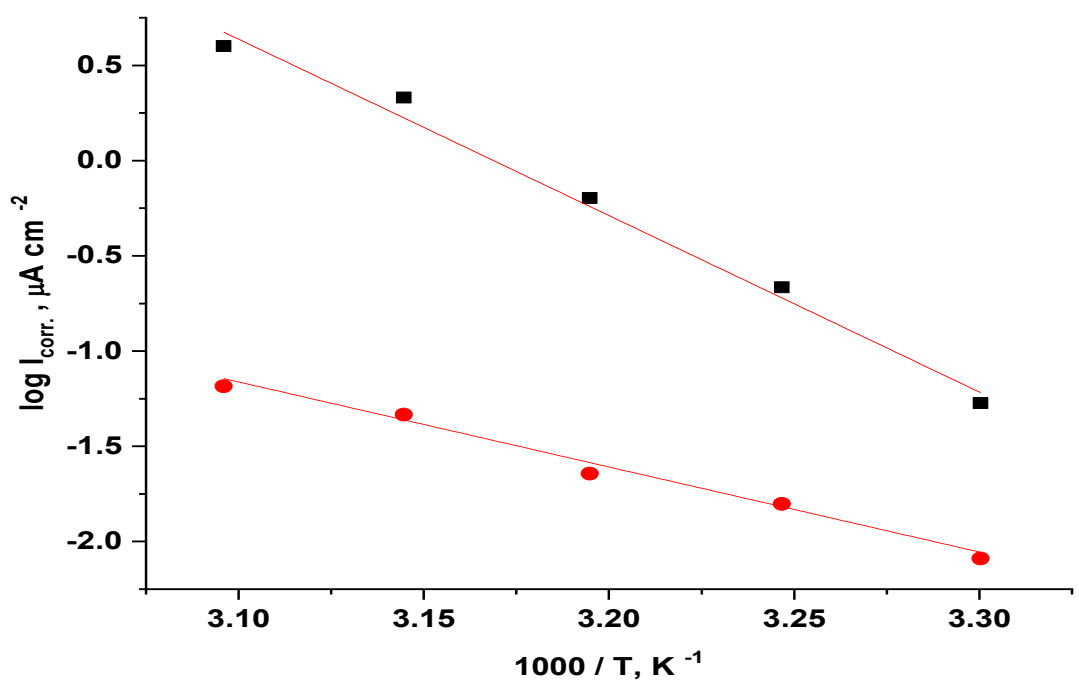

Figure 3. $\log I_{\text {corr }}-1 / T$ plots for the dissolution of $A l$ in $1 \mathrm{M} \mathrm{HCl}$ at $40 \mathrm{ppm}$ of the Candesartan drug

Slika 3. Log Icorr - 1 / T dijagrami za rastvaranje Al u $1 \mathrm{M} \mathrm{HCl}$ na 40 ppm leka Candesartan 


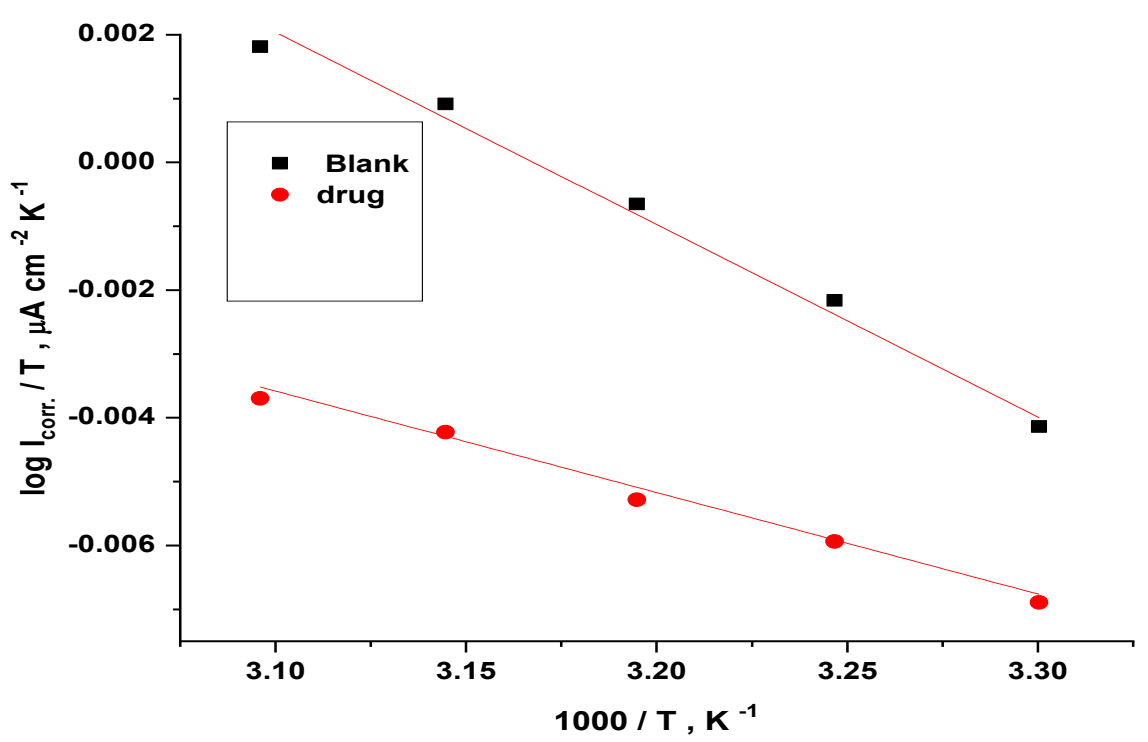

Figure 4. $\log \left(I_{\text {corr }} / T\right)$ - (1/T) plots for the dissolution of $A l$ in $1 \mathrm{M} \mathrm{HCl}$ at $40 \mathrm{ppm}$ of the Candesartan drug

Slika 4. Log (Icorr / T) - (1/T) grafikoni za rastvaranje Al u $1 \mathrm{M} \mathrm{HCl} \mathrm{na} 40$ ppm leka Candesartan

\subsection{AC Impedance test}

The corrosion of $\mathrm{Al}$ in $1 \mathrm{M} \mathrm{HCl}$ in the presence of examined Candesartan drug was investigated by EIS test at $30^{\circ} \mathrm{C}$ after dipping 20 min. "Figs 5 and 6 show Nyquist and Bode curves in the presence and the absence of Candesartan drug, respectively. In both uninhibited and inhibited solutions, all Nyquist plots seem to have a single capacitive loop. The impedance data of $\mathrm{Al}$ dissolution in $1 \mathrm{M} \mathrm{HCl}$ was examined using the fitting circuit model shown in Fig.7 [39] .

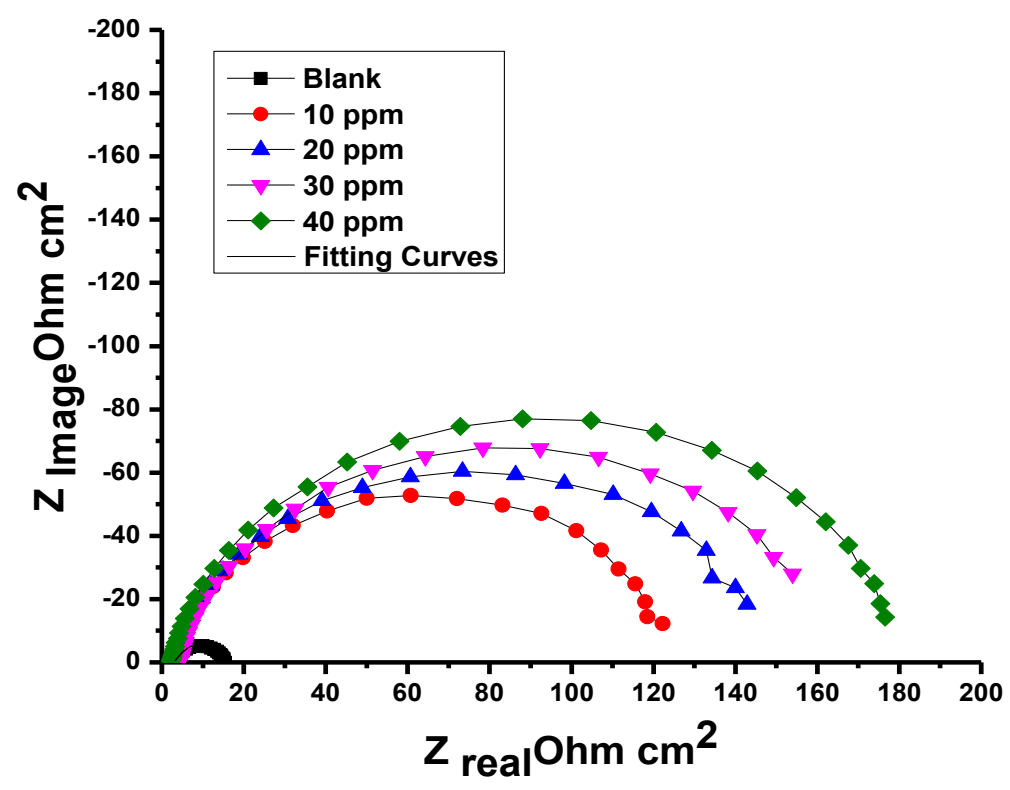

Figure 5. The Nyquist plots for $\mathrm{Al}$ in $1 \mathrm{M} \mathrm{HCl}$ attendance and absence of altered doses of Candesartan drug at $30^{\circ} \mathrm{C}$

Slika 5. Nikuist-ove krive za Al u $1 \mathrm{M} \mathrm{HCl}$ u prisustvu i odsustvu izmenjenih doza leka Candesartan na $30^{\circ} \mathrm{C}$ 


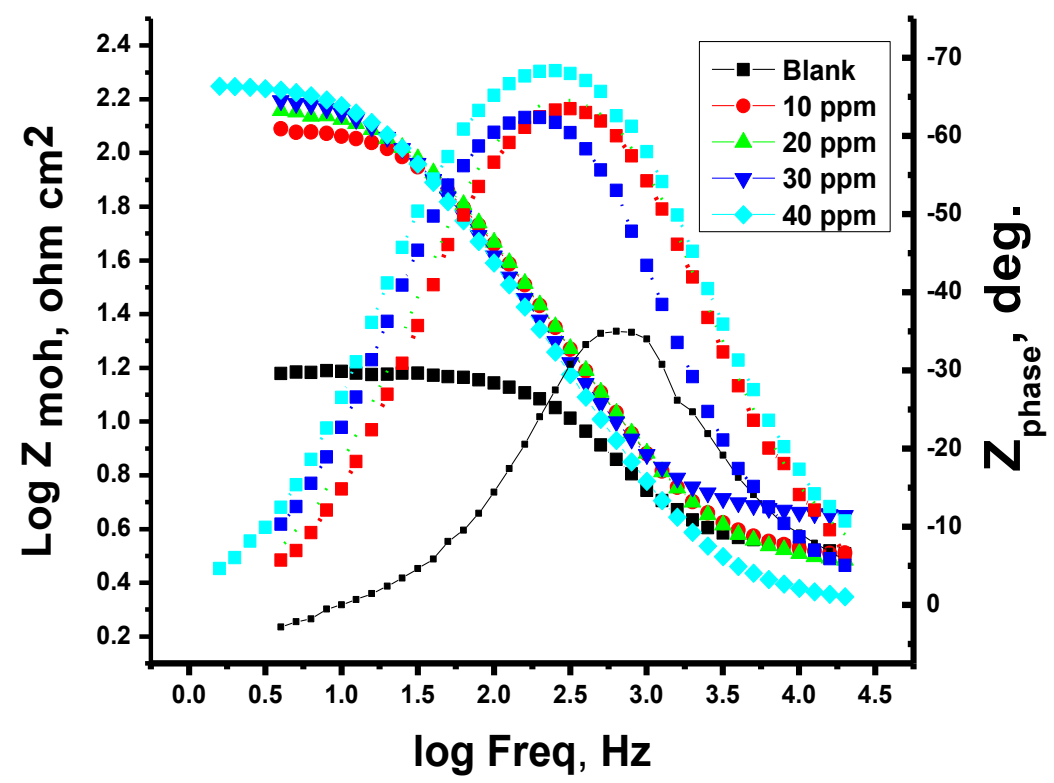

Figure 6. The Bode plots for $\mathrm{Al}$ in $1 \mathrm{M} \mathrm{HCl}$ with and without altered doses of Candesartan drug at $30^{\circ} \mathrm{C}$

Slika 6. Bode krive za Al u $1 \mathrm{M} \mathrm{HCl}$ sa i bez izmenjenih doza leka Candesartan na $30^{\circ} \mathrm{C}$

Figure 7 shows the region of low frequency, and in the presence of "Candesartan drug, the impedance values increase compared to the absence of Candesartan drug, confirming the observed corrosion inhibition of the drug used. Candesartan drug dose also increases, the frequency range increases, and the phase angle reaches its maximum level, suggesting the successful adsorption of this drug molecules on the Al surface [40].

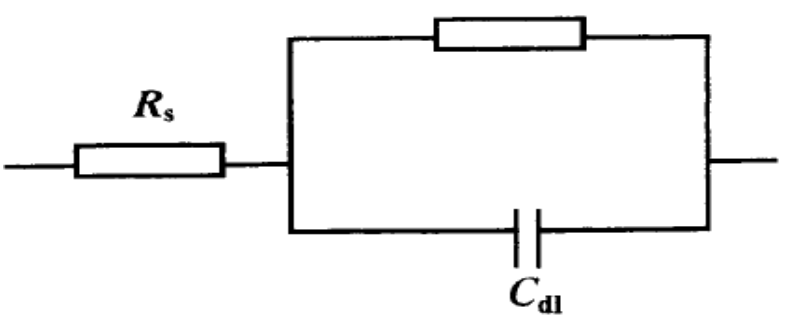

Figure 7. Equivalent circuit model used to fit impedance data

\section{Slika 7. Ekvivalentni model kola koji se koristi za uklapanje podataka o impedansi}

This may be because of the heterogeneity of the Al surface in the presence of the drug (Candesartan compound). The radius of the circle increases as the dose of the Candesartan drug increases, and thus the charge transfer resistance in corrosion reactions increases, according to the Nyquist curves. From all the above, there is high resistance established as the result of adsorption of the Candesartan molecule at the Al solution/interface "'. From the following equation the capacitance double layer $\left(\mathrm{C}_{\mathrm{dl}}\right)$ was calculated:

$$
C_{d l}=1 /\left(2 \pi f_{\max } R_{c t}\right)
$$

Table 3 shows that as the dose of Candesartan drug increases, the values of $C_{d l}$ decrease, "which can be explained by a decrease in the local dielectric constant and/or a rise in the thickness of the electrical double layer [41]. This is due to the adsorption of the Candesartan molecule on the Al/solution interface. Charge transfer, which is primarily responsible for $\mathrm{Al}$ corrosion, is depicted by impedance schemes that are almost semicircular in nature" $[42,43]$.

Table 3. EIS parameters for dissolution of $A l$ in $1 \mathrm{M}$ $\mathrm{HCl}$ at altered doses of Candesartan drug at $30^{\circ} \mathrm{C}$

Tabela 3. EIS parametri za rastvaranje Al u $1 \mathrm{M} \mathrm{HCl}$ u izmenjenim dozama leka Candesartan na $30^{\circ} \mathrm{C}$

\begin{tabular}{|c|c|c|c|c|}
\hline $\begin{array}{c}\text { Conc., } \\
\text { ppm }\end{array}$ & $\mathrm{C}_{\mathrm{dl},} \mu \mathrm{F} \mathrm{cm}^{-2}$ & $\mathrm{R}_{\mathrm{t},} \Omega \mathrm{cm}^{2}$ & $\theta$ & $\mathrm{I} \%$ \\
\hline Blank & 44.57 & 11.36 & ---- & ---- \\
\hline 10 & 28.82 & 109.4 & 0.896 & 89.6 \\
20 & 28.97 & 125.8 & 0.910 & 91.0 \\
30 & 26.19 & 138.8 & 0.918 & 91.8 \\
40 & 27.04 & 159.8 & 0.929 & 92.9 \\
\hline
\end{tabular}




\subsection{Surface morphology}

The 3D micrographs of $\mathrm{Al}$ surface acquired from AFM technique with and without drug are depicted in Fig. (8). Fig. 8 a shows Al surface after immersed in $1 \mathrm{M} \mathrm{HCl}$ solution without drug, average roughness is $202.39 \mathrm{~nm}$. Fig. 8b shows Al surface after submerged in $1 \mathrm{M} \mathrm{HCl}$ with 40 ppm drug, average roughness is $116.45 \mathrm{~nm}$. The average roughness of the drug is less than without drug suggested better adsorption of the drug on Al surface.

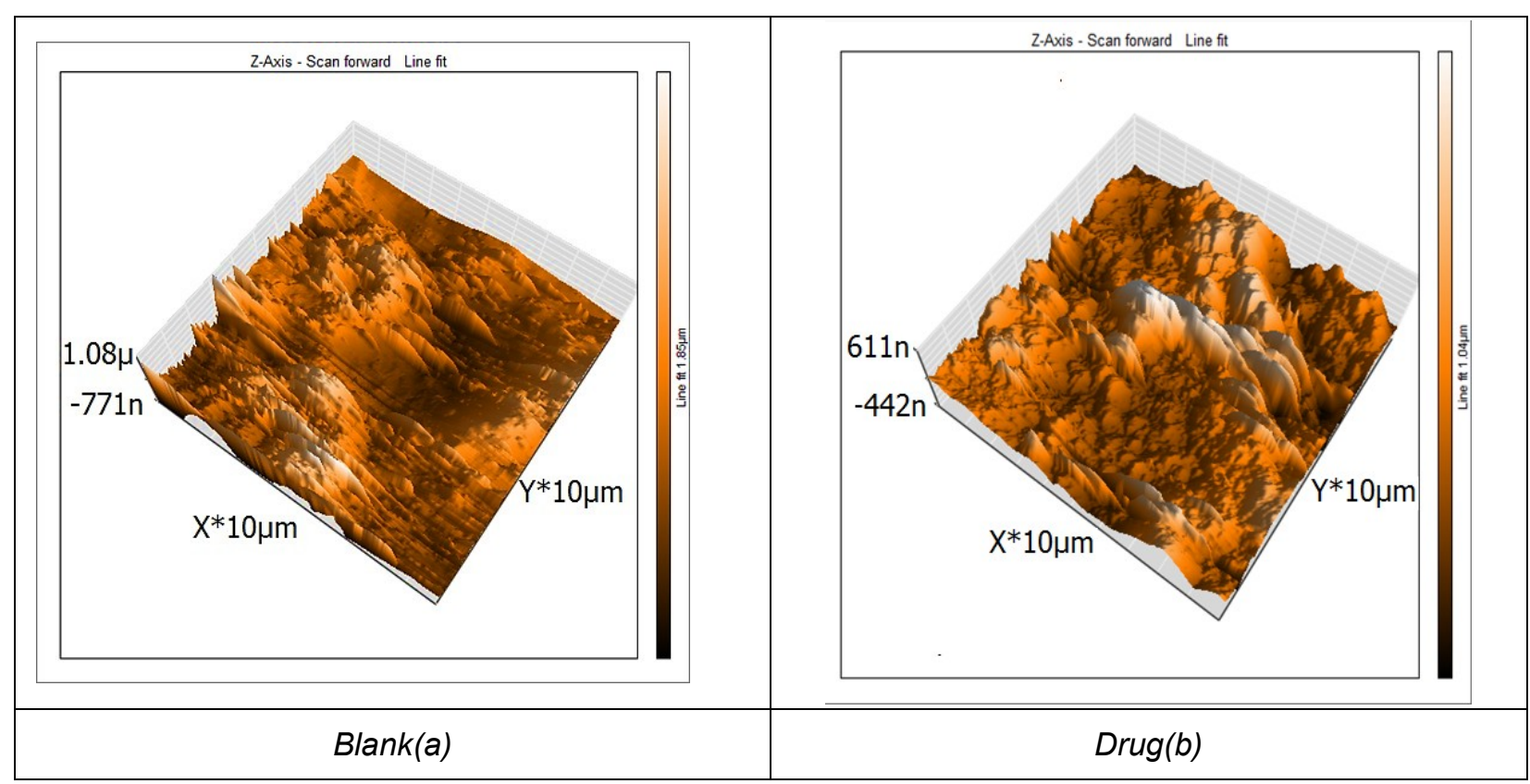

Figure 8. AFM 3D image of Al surface immersed in $1 \mathrm{M} \mathrm{HCl}$ and in $40 \mathrm{ppm}$ of the drug at $30^{\circ} \mathrm{C}$

Slika 8. AFM 3D slika površine Al uronjene u $1 \mathrm{M} \mathrm{HCl}$ i u 40 ppm leka na $30^{\circ} \mathrm{C}$

\subsection{Corrosion inhibition mechanism}

The adsorption of examined Candesartan drug at $\mathrm{Al}$ surface can happened among its active sites of $\mathrm{N}$ and $\mathrm{O}$ atoms in addition to $a \pi$ electron interaction of the benzene nucleus with unshared $p$ of $\mathrm{Al}$ atoms [44]. According to Vijh and Desai et al [45-47], the potential of zero charge (pzc) of $\mathrm{Al}$ in acidic media is negative and is equal to $-0.4 \mathrm{~V}$, so, the pure $\mathrm{Al}$ is negatively charged at $\mathrm{E}_{\text {ocp }}$. Candesartan drug can be protonated in $1 \mathrm{M} \mathrm{HCl}$ medium and become cationic molecule. So, the cationic form of the protonated Candesartan drug molecules can adsorb on the negative charge metal surface by electrostatic attraction forces forming physical adsorption. Candesartan drug is efficient inhibitor because it has $6 \mathrm{~N}$ and $3 \mathrm{O}$ atoms active sites, 3 benzene rings, 2 hetero five-member ring and has high molecular size that covers more surface area when adsorbed on it.

\section{CONCLUSIONS}

The investigated Candesartan drug in $1 \mathrm{M} \mathrm{HCl}$ solution can used as effective corrosion inhibitor for $\mathrm{Al}$ in acid medium. Candesartan drug has an inhibition capacity of 92.9 percent at 40 ppm. The percentage of inhibition increases by raising Candesartan drug dose on the other hand, it decreases by raising the temperature. This suggested that Candesartan drug is physically adsorbed on $\mathrm{Al}$ surface. The adsorption of Candesartan drug on Al surface was found to obey Langmuir adsorption model. Tafel curves confirm that the drug is a mixed type of inhibitor. The results showed that this drug has proven to be an important, environmentally friendly one and lowcost inhibitor.

\section{REFERENCES}

[1] H.Ashassi-Sorkhabi, B.Shabani, B.Aligholipour, D.Seifzadeh (2006) The effect of some Schiff bases on the corrosion of $\mathrm{Al}$ in hydrochloric acid solution, Appl. Surf. Sci., 252 ,4039-4047.

[2] A.Chetouani, B.Hammouti, T.Benhadda, M.Daoudi (2005) Inhibition of pure iron by new synthesized tripyrazole derivatives in $\mathrm{HCl}$ solution, Appl. Surf. Sci., 249, 375-385.

[3] P.C.Okafor, Y.Zheng (2009) Synergistic inhibition behavior of methylbenzyl quaternary imidazoline derivative and iodide ions on mild steel in $\mathrm{H}_{2} \mathrm{SO}_{4}$ solutions, Corros. Sci., 51, 850-859. 
[4] S.AUmoren, O.Ogbobe, E.E.Ebenso (2006) The Inhibition of aluminum corrosion in hydrochloric acid solution by exudate gum from Raphia hookeri, Bull. Electrochem., 22 (4), 155-167.

[5] E.E.Ebenso, H.Alemu, S.A.Umoren, I.B.Obot (2008) Inhibition of Mild Steel Corrosion in Sulfuric Acid Using Alizarin Yellow GG Dye and Synergistic lodide Additive, Int. J. Electrochem. Sci., 3, 13251339.

[6] H.Ju, Y.Li (2007) Nicotinic acid as a nontoxic corrosion inhibitor for hot dipped $\mathrm{Zn}$ and $\mathrm{Zn}-\mathrm{Al}$ alloy coatings on steels in diluted hydrochloric acid, Corros. Sci., 49, 4185-4201.

[7] A.S.Fouda, G.Y.Elewady, A.El-Askalany, K.Shalabi (2010) Inhibition of aluminium corrosion in hydrochloric acid media by three Schiff base compound, Zastita materijala, 51(4), 205-221.

[8] G.Y.Elewady, I.A.El-Said, A.S.Fouda (2008) Effect of anions on the corrosion inhibition of $\mathrm{Al}$ in $\mathrm{HCl}$ using ethyl trimethyl ammonium bromide as cationic inhibitor, Int. J. Electrochem. Sci., 3, 644.-655.

[9] W.Li, G.He, C.Pei, B.Hou (2007) Electrochemical and thermodynamic investigation of diniconazole and triadimefon as corrosion inhibitors for copper in synthetic seawater, Electrochim. Acta, 52, 6386.6394.

[10] M.Bouklah, B.Hammouti, M.Lagrenee, F.Bentiss (2006) The inhibited effect of some tetrazolic compounds towards the corrosion of brass in nitric acid solution, Corros. Sci., 48, 2831-2842.

[11] M.Benabdellah, R.Touzani, A.Aouniti, A.Dafali, S.ElKadiri, B.Hammouti, M. Benkaddour (2007) Inhibitive action of some bipyrazolic compounds on the corrosion of steel in $1 \mathrm{M} \mathrm{HCl}$, Mater. Chem. Phys., 105, 373-379.

[12] A.Yildirim, M.Cetin (2008) Synthesis and evaluation of long new alkyl side chain acetamide, isoxazolidine and isoxazoline derivatives as corrosion inhibitors, Corros. Sci., 50, 155.-165.

[13] Y.Harek, L.Larabi (2004) Corrosion inhibition of mild steel in $1 \mathrm{~mol} \mathrm{Hcl}$ by Oxalic N-phenylhydruzide N'phenylthiosemicarbazide, Kem. Ind., 53 (2), 55-61.

[14] A.Fiala, A.Chibani, A.Darchen, A.Boulkamh, K.Djebbar (2007) Investigations of the inhibition of copper corrosion in nitric acid solutions by ketene dithioacetal derivatives, Appl. Surf. Sci., 253, 93479356.

[15] R.Hasanov, M.Sadikoglu, S.Bilgic (2007) Adsorption properties and inhibition of mild steel corrosion in sulphuric acid solution by ketoconazole. Appl. Surf. Sci., 253, 3913.-3921.

[16] M.S. Morad (2005) Effect of amino acids containing sulfur on the corrosion of mild steel in phosphoric acid solutions containing $\mathrm{Cl}^{-}, \mathrm{F}^{-}$and $\mathrm{Fe}^{3+}$ ions, J. Appl. Electrochem., 35, 889-895

[17] M.Ozcan, R.Solmaz, G.Kardas, I.Dehri (2008) Adsorption Properties of Barbiturates as Green Corrosion Inhibitors on Mild Steel in Phosphoric Acid, Colloid Surf. A Physicochem. Eng.Aspects.,12, 325-357.
[18] G.Kardas, R.Solmaz (2006) Adsorption and Corrosion Inhibition Effect of 1,1'Thiocarbonyldiimidazole on Mild Steel in $\mathrm{H}_{2} \mathrm{SO}_{4}$ Solution and Synergistic Effect of lodide Ion, Corros. Rev., 24, 151-171.

[19] G.Kardas (2005) The Inhibition Effect of 2Thiobarbituric Acid on the Corrosion Performance of Mild Steel in $\mathrm{HCl}$ Solutions, Mater. Sci., 41, 337 343.

[20] A.H.Ali, A.El-Aziz S.Fouda, A.H.Tilp (2020) Electrochemical behavior for corrosion protection of mild steel (MS) in $1 \mathrm{M} \mathrm{HCl}$ medium by using lidocaine drug as an inhibitor, Zastita Materijala, 61 (4), 286-306.

[21] S. Hari Kumar, S.Karthikeyan (2012) Inhibition of mild steel corrosion in hydrochloric acid solution by Cloxacillin drug, Journal of Materials and Environmental Science, 3, 925-934.

[22] A. El-Aziz S.Fouda, F.I.El-Dossoki, E.A.Sello (2019) Esomeprazole Magnesium Trihydrate drug as a potential non-toxic corrosion inhibitor for mild steel in acidic media, Zastita Materijala 60 (3), 237-245.

[23] I.Naqui, A.R.Saleemi., S.Naveed (2011) Cefixime: A drug as efficient corrosion inhibitors for mild steel in acidic media. Electrochemical \& Thermodynamic studies, Int. J. Electrochem. Sci., 6, 146- 161.

[24] A.El-Aziz S.Fouda, S.A.El-Maksoud, S. A. El-Salam (2017) Mitigation of corrosion of carbon steel in acid medium using some antipyrine derivatives, Zastita Materijala, 58(1), 5-17.

[25] [25] A.K.Singh, S.K.Singh, E.E Ebenso (2011) Cefacetrile as corrosion inhibitors for mild steel in acidic media", International Journal of Electrochemical Science, 6, 5689-5700.

[26] A.S.Fouda, A.H.Ali (2018) Egy- dronate drug as promising corrosion inhibitor of $\mathrm{C}$ - steel in aqueous medium, Zastita materijala, 59(1), 126-141.

[27] G. Gece (2011) Drugs: A review of promising novel corrosion inhibitors, Corros. Sci., 53, 3873-3898.

[28] M.Abdallah (2004) Antibacterial drug as corrosion inhibitors for corrosion of Aluminum in hydrochloric acid solution", Corrosion Science, 46, 1981-1996.

[29] A.K.Singh, M.A.Quraishi (2010) Effect of Cefazolin on the corrosion of mild steel in Hydrochloric acid solution, Corrosion Science, 52,152-160.

[30] A.S.Fouda, A.Y.El-Khateeb, N.M.Elbahrawi (2017) Cupressus sempervirens extract as green inhibitor for corrosion of carbon steel in hydrochloric acid solutions, Zastita materijala, 58(2), 131-145.

[31] S.K.Shukla, M.A.Quraishi (2010) Cefalexin drug: A new and efficient corrosion inhibitors for mild steel in hydrochloric acid solution. Mater Chem. Phys., 120,142- 147.

[32] A.S.Fouda, M.Morsi, H.A.Mosallam (2016) Capsicum extract as green corrosion extract for carbon steel in hydrochloric acid solutions, Zastita materijala, 57(1), 33-47.

[33] A.S.Fouda, M.A.Abd El-Ghaffar, M.H.Sherif, A.T.ElHabab, A.El-Hossiany (2020) Novel Anionic 4-TertOctyl Phenol Ethoxylate Phosphate Surfactant as 
Corrosion Inhibitor for C-steel in Acidic Media, Prot. Metals Phys. Chem.Surf., 56 (1), 189-201.

[34] M.M.Motawea, A.El-Hossiany, A.S.Fouda (2019) Corrosion Control of Copper in Nitric Acid Solution using Chenopodium Extract, Int. J. Electrochem. Sci., 14, 1372-1387.

[35] G.Moretti, G.Quartarone, A.Tassan, A.Zingales (1994) An investigation of some Schiff bases as corrosion inhibitors for austenitic chromium-nickel steel in $\mathrm{H}_{2} \mathrm{SO}_{4}$, Werkst. Korros., 45, 641-647.

[36] I.N.Putilova, S.A.Balezin, V.P.Barannik (1960) Effect of azole compounds on corrosion of copper in acid medium, Metallic Corrosion Inhibitors, Pergamon, Oxford, p.76

[37] I.N.Putilova, S.A.Balezin, V.P.Barannik, T.Baba (1962) The effect of pyrrole-halide mixtures in inhibiting the dissolution of low-carbon steel in sulphuric acid, Corros. Sci., 2, 22-27.

[38] A.S.Fouda, S.A.Abd El-Maksoud, A.M.Belal, A.ElHossiany, A.Ibrahium (2018) Effectiveness of Some Organic Compounds as Corrosion Inhibitors for Stainless Steel 201 in $1 \mathrm{M} \mathrm{HCl}$ : Experimental and Theoretical Studies, Int. J. Electrochem. Sci., 13, 9826-9846.

[39] L.Larabi, O.Benali, S.M.Mekelleche, Y.Harek (2006) Adsorption Behavior and Inhibition Corrosion Effect of Sodium Carboxymethyl Cellulose on Mild Steel in Acidic Medium, J. Appl. Surf. Sci., 253:1371-1378.

[40] A.S.Fouda, M.Abdel Azeem, S.A.Mohamed, A.ElHossiany, E.El-Desouky (2019) Corrosion Inhibition and Adsorption Behavior of Nerium Oleander Extract on Carbon Steel in Hydrochloric Acid Solution, Int. J. Electrochem. Sci., 14, 3932-3948.

[41] M.Lagrenee, B.Mernari, B.Bounais, M.Traisnel, F.Bentiss (2002) Effect of iodide ions on corrosion inhibition of mild steel by 3,5-bis(4methylthiophenyl)-4H-1,2,4-triazole in sulfuric acid solution, Corros. Sci. 44:573-588.

[42] D.Schweinsberg, G.George, A.Nanayakara, D.Steiner (1988) The protective action of epoxy resins and curing agents-inhibitive effects on the aqueous acid corrosion of iron and steel, Corros.Sci., 28, 33-42.

[43] A.S.Fouda, M.N.Moussa, F.I.Taha, A.I.Elneanaa (1986) The role of some thiosemicarbazide derivatives in the corrosion inhibition of $\mathrm{Al}$ in $\mathrm{HCl}$, Corros. Sci., 26, 719-726.

[44] F.Bentiss, M.Traisnel, M.Lagrene (2000) Inhibition of acidic corrosion of mild steel by 3,5-diphenyl-4H1,2,4-triazole, Appl. Surf. Sci., 161,194-202.

[45] A.K.Vijh (1968) Hydrogen-evolution reaction on Al, J. Phys. Chem., 72,1148-1156.

[46] M.N.Desai (1972) Corrosion Inhibitors for Aluminum Alloys, Werkst. Korros., 23,475-482.

[47] A.S. Fouda, N. E.Al-Hazmi, H. H. El-Zehry, A. ElHossainy (2020), Electrochemical and Surface Characterization of Chondria Macrocarpa Extract $(\mathrm{CME})$ as Save Corrosion Inhibitor for Aluminum in $1 \mathrm{M} \mathrm{HCl}$ Medium, J.Applicable Chem., 9(3), 362382.

\section{IZVOD}

\section{CANDESARTAN: FARMACEUTSKI PROIZVOD KAO EFIKASNI INHIBITOR KOROZIJE ZA ALUMINIJUM U KISELOM RASTVORU}

Ispitivane su performanse korozije aluminijuma u $1 \mathrm{M}$ rastvoru hlorovodonične kiseline u prisustvu i odsustvu leka Candesartan primenom postupaka potenciodinamičke polarizacije (PDP) $i$ AC impedanse (EIS). Utvrdeno je da su na efikasnost inhibicije (\% IE) leka Candesartan uticale njegove doze $i$ temperatura $i$ dostigla je $92,9 \%$ pri $40 \times 10^{-6} \mathrm{M}$ na $30^{\circ} \mathrm{C}$. Izoterma adsorpcije se slaže sa Langmuirovim modelom. Prema podacima Tafela, ispitivani lek Candesartan deluje kao inhibitor mešovite vrste. Takođe, proučavan je i objašnjen uticaj temperature na brzinu rastvaranja i termodinamičke parametre u prisustvu i odsustvu leka Candesartan. Svi testovi su dali slične rezultate.

Ključne reči: inhibicija korozije, aluminijum, HCl, lek Candesartan, adsorpcija, impedansa, polarizacija.

Naučni rad

Rad primljen: 03. 05. 2021

Rad prihvaćen: 15. 07. 2021.

Rad je dostupan na sajtu: www.idk.org.rs/casopis

(C) 2021 Authors. Published by Engineering Society for Corrosion. This article is an open access article distributed under the terms and conditions of the Creative Commons Attribution 4.0 International license (https://creativecommons.org/licenses/by/4.0/) 